\title{
Hepatitis B reactivation after HCV treatment with sofosbuvir/ledipasvir in a HIV-coinfected patient with previous positive anti-HBs antibody: a case report and a review of literature
}

\author{
Cristina Soeiro, Ana P. Tavares, Rui Sarmento e Castro \\ Infectious Diseases Department, Centro Hospitalar do Porto, Portugal
}

\begin{abstract}
Chronic hepatitis B (HBV) and C (HCV) coinfection are frequently observed in clinical practice. The interaction between HCV and HBV is complex and not completely understood, and usually results in the suppression of hepatitis B replication by HCV superinfection or coinfection. Cases of hepatitis $B$ reactivation during and after HCV treatment with direct acting antivirals (DDA) have been described, and it is recommended to screen all patients starting DAA therapy for HBV infection markers and to monitor those that have positive markers of $\mathrm{HBV}$ infection. HBs antigen (HBsAg) positivity is the main risk factor for HBV reactivation, and this phenomenon is rarer in those with "resolved" $\mathrm{HBV}$ infection (negative $\mathrm{HBsAg}$, positive antiHBc antibody (HBcAb) and anti-HBs antibody (HBsAb) positive or negative). The authors present a case of HBV reactivation after HCV treatment with sofosbuvir/ ledipasvir that occurred in a 54-year-old male that was HIV-coinfected and had "resolved" hepatitis $\mathrm{B}$ infection (negative $\mathrm{HBsAg}$, positive $\mathrm{HBcAb}$ and positive $\mathrm{HBs} \mathrm{Ab}$ ). Our case reinforces the need to screen all patients who will start DAA therapy for hepatitis $\mathrm{C}$ infection, and alerts clinicians to the need to closely monitor patients with evidence of previous HBV infection no only during treatment but also after HCV treatment with DAAs.
\end{abstract}

HIV AIDS Rev 2018; 17, 2: 146-151 DOI: https://doi.org/10.5114/hivar.2018.76378

Key words: DAA, HCV, HBV reactivation.

\section{Introduction}

Due to their shared routes of acquisition, coinfection with human immunodeficiency virus (HIV) and hepatitis B (HBV) and/or hepatitis $\mathrm{C}(\mathrm{HCV})$ is common. The World Health Organization (WHO) estimates that $2-15 \%$ of HIV-infected people worldwide (and up to $90 \%$ of those who acquired the infection through intravenous drug usage) are coinfected with HCV (approximately 2.75 million people), and that chronic HBV coinfection affects $5-20 \%$ of HIV-infected pa-

Address for correspondence: Dr. Cristina Soeiro, Infectious Diseases Department, Centro Hospitalar do Porto, Largo do Prof. Abel Salazar, 4099-001 Porto, Portugal, phone: 00351222077500, e-mail: cristinaaspsoeiro@hotmail.com tients (approximately 2.6 million) [1]. The interaction between $\mathrm{HBV}$ and HCV in patients coinfected with both viruses usually results in the predominance in of one of the viruses over the other, and hepatitis B replication may be suppressed by HCV superinfection or coinfection [2].

There have been reports of hepatitis $B$ reactivation after chronic HCV treatment with pegylated-interferon (pegINF) and ribavirin (RBV), in spite of the fact that these drugs are active against HBV, especially when sustained virological response (SVR) was achieved $[3,4]$. The new direct antivi-
Article history:

Received: 21.08.2017

Received in revised form: 23.11.2017

Accepted: 10.01.2018

Available online: 21.05.2018
International Journal of HIV-Related Problems

HIV \& AIDS

R e vi e w 
rals (DAAs) against HCV are safe and well tolerated, even in HIV-infected patients, but have no activity against HBV [5]. Reports of hepatitis B reactivation after HCV treatment with DAAs have been published [6-15], and led the European Medicine Agency (EMA) and the Food and Drug Administration (FDA) to investigate the risk of $\mathrm{HBV}$ reactivation with these drugs and to recommend hepatitis B screening in all patients proposed to initiate DAAs treatment $[16,17]$.

Current HCV treatment guidelines advise the need to check for HBV serostatus in those initiating HCV treatment with DAAs and warn about the risk of HBV reactivation, but provide no guidance on how to monitor these patients [18-20].

The authors present one case of hepatitis $\mathrm{B}$ reactivation after HCV treatment and review the published literature on this topic.

\section{Case report}

A 54-year-old male was presented in our department with HIV-1 infection, and for chronic hepatitis C evaluation and treatment.
He was diagnosed with $\mathrm{HIV} / \mathrm{HCV}$ coinfection acquired by intravenous drug use in 1995. He initiated antiretroviral therapy (ARV) in 1999 with stavudine ( $\mathrm{d} 4 \mathrm{~T}$ ) plus didanosine (ddI) that was changed in 2002 to d4T, lamivudine (3TC), and nevirapine (NVP). He abandoned follow-up and therapy in 2004, but reinitiated ARV in 2014 with abacavir (ABC), 3TC, and efavirenz (EFV) that he was still taking with good adhesion at the time of referral. Analytically, he had $521 \mathrm{CD} 4 / \mathrm{mm}^{3}$ and undetectable HIV RNA.

Regarding HCV infection, he was a genotype 1a with baseline HCV RNA of 9,230,000 UI/ml (6.97 log). At baseline, serum aspartate aminotransferase (AST) and alanine aminotransferase (ALT) levels were 3.5 times the upper normal limit (122 and $125 \mathrm{UI} / \mathrm{l}$, respectively), and he had an interleukin 28-B genotype CC. He had a transitory hepatic elastography (FibroScan ${ }^{\otimes}$ ) of $19.0 \mathrm{KPa}$, a Child-Pugh score A (5 points), and a MELD score of 7 points. He was treatment naïve, as he always refused treatment with pegylated-interferon and ribavirin; the abdominal ultrasound showed hepatosplenomegaly and signs of hepatic steatosis. The upper endoscopy showed no signs of portal hypertension.

A Started tenofovir

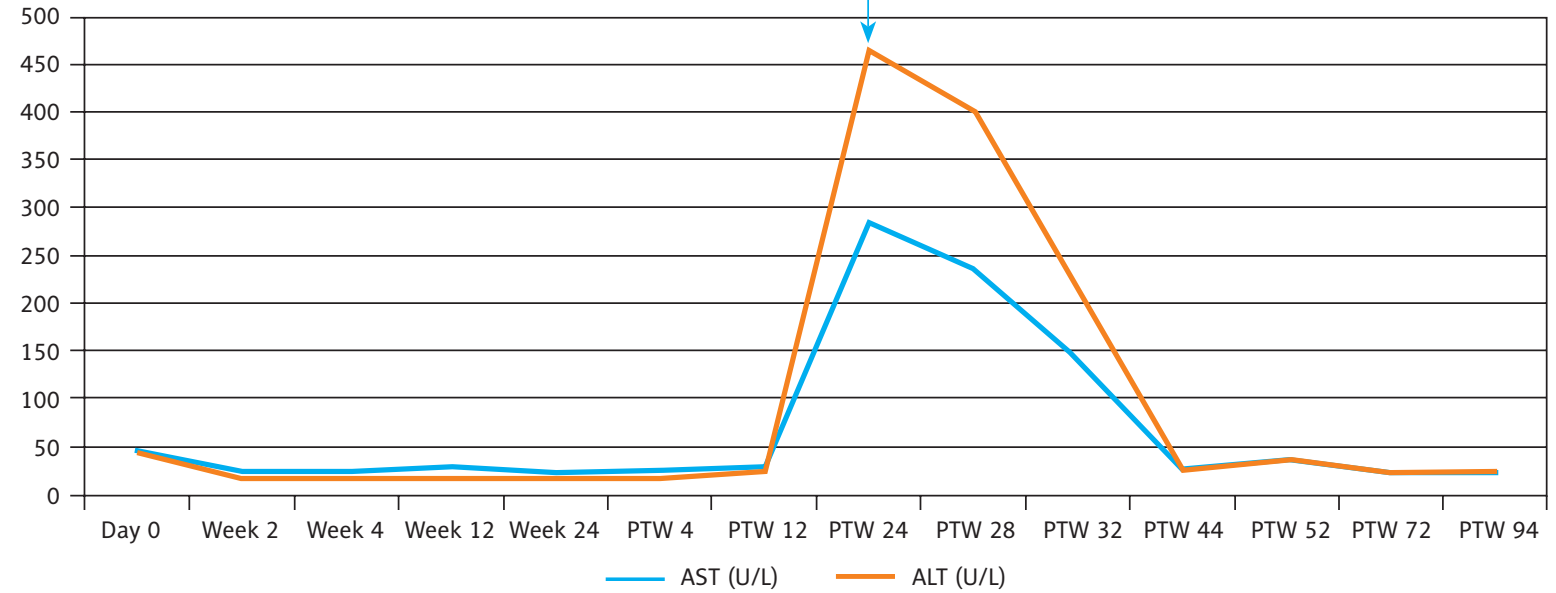

B

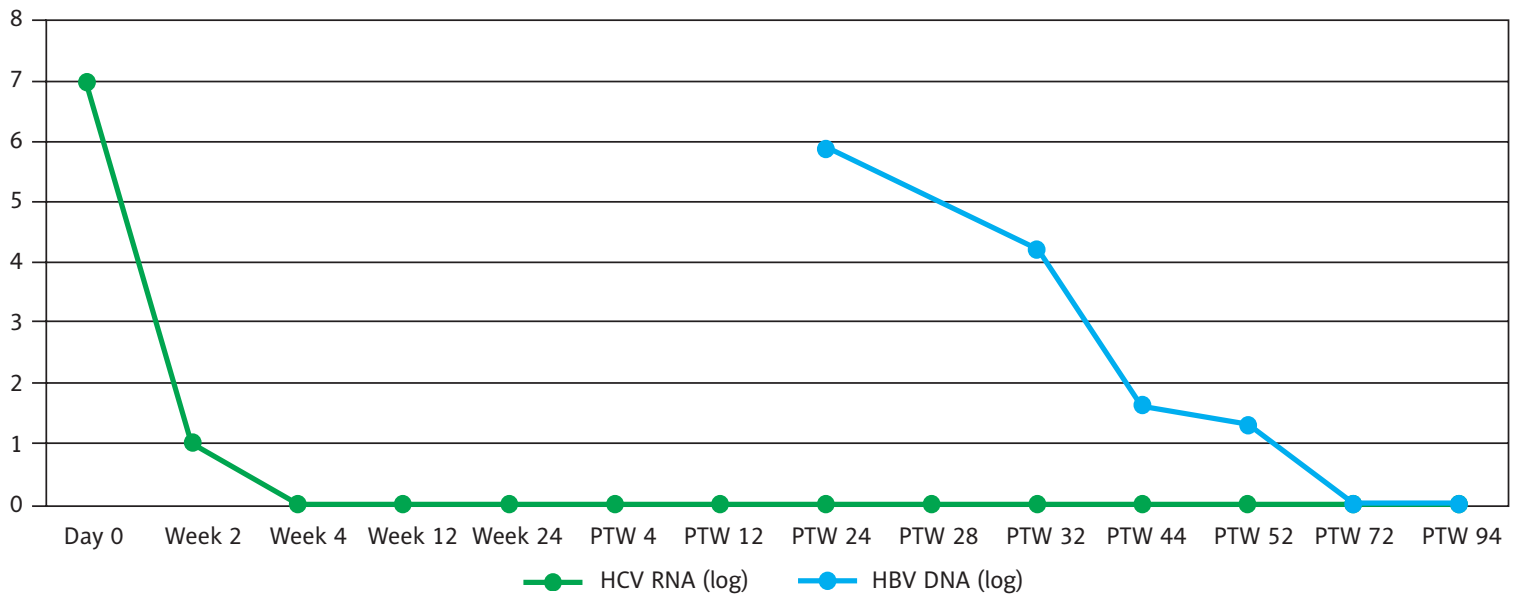

AST - serum aspartate aminotransferase, ALT - alanine aminotransferase, PTW - week post-treatment

Fig. 1. A) Aminotransferases evolution during and after HCV treatment. B) HCV RNA and HBV DNA evolution during and after HCV treatment 
At the time of HIV/HCV diagnosis (1995), he had markers of a "resolved" hepatitis B infection - Hbs antigen (HBsAg) negative, anti-HBc antibody ( $\mathrm{HBcAb}$ ) positive, anti-HBs antibody (HBsAb) negative, anti-HBe antibody ( $\mathrm{HBeAb}$ ) positive. In 2009, these markers were repeated and confirmed the "resolved" infection (HBsAg negative, $\mathrm{HBcAb}$ positive, $\mathrm{HBsAb}-75.42 \mathrm{UI} / \mathrm{l}$ ).

He also had a history of chronic alcoholism (he was abstinent of alcohol for 3 months, but he used to consume more than $70 \mathrm{~g} /$ day) and was a smoker (21 pack-years). He was receiving lorazepam for anxiety but had no other co-medications.

Before treatment, screening tests for other causes of chronic hepatitis were performed and were negative, including auto-immune hepatitis, Wilson's disease, and hemochromatosis.

He was treated with sofosbuvir/ledipasvir for 24 weeks without any intercurrences. By the second week of treatment, aminotransferases had normalized (AST 24 U/l, ALT $17 \mathrm{U} / \mathrm{l}$ ) and he had a still positive but unquantifiable HCV viral load. At the end of the treatment, the patient had normal aminotransferases, HCV RNA and HIV RNA were undetectable, CD4 cell count was 934 cells $/ \mathrm{mm}^{3}$. Liver ultrasound was repeated showing no new alterations.

He was reevaluated 4 and 12 weeks after the end of treatment: he remained asymptomatic and his blood tests showed no abnormalities; he achieved sustained SVR12. His ARV medication was altered to $\mathrm{ABC} / 3 \mathrm{TC}$ and dolutegravir (DTG) because of neuropsychiatric complaints that were attributed to EFV. He was reevaluated 6 weeks after this change was made and no abnormality was detected.

At his 24 weeks post-treatment visit, in spite of having no symptoms, there was a steep increase in aminotransferases level (AST $375 \mathrm{U} / \mathrm{l}$, ALT $678 \mathrm{U} / \mathrm{l}$ ). There was no history of acute infections, use of new drugs or herbal products, alcohol consumption, or illicit drugs use. His HCV RNA remained undetectable and the study of auto-immune hepatitis was repeated but remained normal. HBV DNA quantification was then performed, showing an HBV DNA of $742,000 \mathrm{UI} / \mathrm{ml}$. Serological markers for $\mathrm{HBV}$ were repeated and showed HBsAg reverse seroconversion: HBsAg positive, $\mathrm{HBcAb}$ positive, $\mathrm{HBs} \mathrm{Ab}$ negative, $\mathrm{HBeAb}$ negative, $\mathrm{HBeAg}$ positive. ARV medication was altered to tenofovir/ emtricitabine and DTG (he had a drug susceptible genotype D HBV virus). We assisted to a normalization of his liver enzymes.

At the time of writing this paper, approximately 17 months after the HBV reactivation, the patient remains asymptomatic. His AST level is normal (18 U/l), HBV DNA is undetectable (less than $10 \mathrm{UI} / \mathrm{ml}$ ), as is HCV RNA (less than $15 \mathrm{UI} / \mathrm{ml})$.

The evolution of analytical parameters during treatment and follow-up are shown in Figure 1.

\section{Discussion}

Hepatitis B reactivation after treatment of chronic hepatitis $\mathrm{C}$ with pegylated-interferon and ribavirin has been described and was mostly attributed to the end of the HCV suppressive effect on HBV replication after SVR achievement $[4,21]$. Some authors believe that this phenomenon was less likely to occur with the interferon-based treatments due to the anti-HBV effect of these drugs that DAAs do not possess [21]. Besides not being active against HBV, DAAs achieve high SVR12 rates and very steep decreases in HCV RNA $[7,22]$, which may predispose to an increase in the number of $\mathrm{HBV}$ reactivations occurring after HCV treatment.

From 22 November 2013 to 15 October 2016, 29 cases of $\mathrm{HBV}$ reactivation related to DAA treatment were reported to the U.S.F.D.A. Adverse Event Reporting System [15]. Other case reports have also been published [6-14], whose main characteristics are shown in Table 1.

In most cases described so far, hepatitis $\mathrm{B}$ reactivation occurred either during treatment or immediately after. In case 3, there is an evidence of increased HBV replication as soon as two weeks after the beginning of treatment [7], indicating that HBV replication increases shortly after DAAs initiation. Likewise, in the review of cases reported to the FDA, the median time from DAA starting to HBV reactivation was 53 days, and $\mathrm{HBV}$ reactivation usually occurred 4-8 weeks after DAAs initiation [15]. However, our case shows that the risk of reactivation is maintained after treatment, since our patient showed analytical alterations 6 months after the end of treatment, which also occurred in case 7 [11]. The risk of late HBV reactivation had already been demonstrated in a small study by Wahle et al. of a cohort of $10 \mathrm{HCV} / \mathrm{HBV}$ coinfected patients from a hemodialysis center. The study showed that after HCV treatment with pegylated-interferon and ribavirin, most $\mathrm{HBV}$ reactivations occurred at a late stage (mean time, $22 \pm 9$ months) [23].

Despite these reports, $\mathrm{HBV}$ reactivation risk in patients treated with DAAs seems to be low and most frequent in $\mathrm{HBsAg}$ positive patients. Sulkowski et al. analyzed retrospectively blood samples of $103 \mathrm{HCV}$ patients with $\mathrm{HBcAb}$ positivity and found no HBV reactivations cases [24]. Similarly, a retrospective analysis of 62,290 $\mathrm{HCV}$-infected veterans treated with DAAs, of which 377 had a positive HBsAg and 18,426 were $\mathrm{HBcAb}$ positive, found only $9 \mathrm{HBV}$ reactivation cases ( 8 in HBsAg positive cases and 1 patient with an isolated $\mathrm{HBcAb}$ ). Of note, this analysis excluded HBsAb positive patients who were considered to have a low-risk of reactivation [25]. Liu et al. presented a prospective cohort study of $81 \mathrm{HBsAg}$ negative and $12 \mathrm{HBsAg}$ positive $\mathrm{HBV} / \mathrm{HCV}$ co-infected patients, in which only two of the $12 \mathrm{HBs} A g$ positive (16.7\%) and none of the $81 \mathrm{HBsAg}$ negative patients had HBV reactivation [26]. These results confirmed the observations of several studies. Wang et al. evaluated 327 DAA treated patients and identified 3 cases of HBV reactivation in $10 \mathrm{HBsAg}$ positive patients and no cases of reactivation in $124 \mathrm{HBsAg}$ negative patients with positive HBV DNA [27]. Londoño et al. evaluated $10 \mathrm{HBsAg}$ positive and $64 \mathrm{HBcAb}$ positive patients, and $\mathrm{HBV}$ reactivation rates were $50 \%$ $(n=5)$ and $1.6 \%(n=1)$, respectively [28]. Another study by Yue et al. showed similar results: 4 out of $7 \mathrm{HBsAg}$ positive patients had $\mathrm{HBV}$ reactivation, but none of the $57 \mathrm{HBcAb}$ 
Table 1. Cases of HBV reactivation after HCV treatment with direct antiviral agents

\begin{tabular}{|c|c|c|c|c|c|c|c|c|}
\hline Case & $\begin{array}{l}\text { Age, } \\
\text { gender }\end{array}$ & $\begin{array}{l}\text { HBV } \\
\text { status }\end{array}$ & $\mathrm{HCV}$ & Cirrhosis & HIV & $\begin{array}{c}\text { DAA } \\
\text { regimen }\end{array}$ & Presentation & Treatment \\
\hline $1[6]$ & $\begin{array}{l}69 \text { yo, } \\
\text { male }\end{array}$ & $\begin{array}{l}\text { Inactive } \\
\text { chronic } \\
\text { hepatitis }\end{array}$ & $\begin{array}{c}\text { G1a } \\
\text { Treatment naïve }\end{array}$ & No & No & $\mathrm{DCV}+\mathrm{ASU}$ & $\begin{array}{c}\text { W4 HCV } \\
\text { treatment: } \\
\text { aminotransferases } \\
\text { elevation }\end{array}$ & ETC \\
\hline $2[7]$ & $\begin{array}{l}55 \text { yo, } \\
\text { male }\end{array}$ & $\begin{array}{l}\text { Inactive } \\
\text { chronic } \\
\text { hepatitis }\end{array}$ & $\begin{array}{c}\text { G1a } \\
\text { Treatment } \\
\text { experienced } \\
\text { (peg-IFN + RBV) }\end{array}$ & Child A & No & $\mathrm{SOF}+\mathrm{SIM}$ & $\begin{array}{c}\text { W7 HCV } \\
\text { treatment: } \\
\text { malaise, nausea, } \\
\text { epigastric pain, } \\
\text { jaundice, tender } \\
\text { hepatomegaly }\end{array}$ & TDF/FTC \\
\hline $3[7]$ & $\begin{array}{l}57 \text { yo, } \\
\text { male }\end{array}$ & $\begin{array}{c}\text { Occult } \\
\text { infection }\end{array}$ & $\begin{array}{c}\text { G1a } \\
\text { Treatment } \\
\text { experienced } \\
\text { (pegINF + RBV) }\end{array}$ & No & No & $\mathrm{SOF}+\mathrm{SIM}$ & $\begin{array}{l}\text { W2 and W4 } \\
\text { HCV treatment: } \\
\text { asymptomatic; } \\
\text { detectable } \\
\text { HBV DNA }\end{array}$ & TDF \\
\hline $4[8]$ & $\begin{array}{l}59 \text { yo, } \\
\text { female }\end{array}$ & $\begin{array}{l}\text { "Resolved" } \\
\text { infection }\end{array}$ & $\begin{array}{c}\text { G1b } \\
\text { Treatment } \\
\text { experienced } \\
\text { (standard INF + RBV) }\end{array}$ & No & No & SOF + SIM & $\begin{array}{l}\text { W7 HCV } \\
\text { treatment: } \\
\text { liver failure }\end{array}$ & $\begin{array}{c}\text { TDF, liver } \\
\text { transplantation }\end{array}$ \\
\hline $5[9]$ & $\begin{array}{l}59 \text { yo, } \\
\text { male }\end{array}$ & $\begin{array}{l}\text { "Resolved" } \\
\text { infection }\end{array}$ & $\begin{array}{c}\text { G4d } \\
\text { Experienced } \\
\text { (pegINF + RBV) }\end{array}$ & No & Yes & SOF/LDV & $\begin{array}{l}\text { W1 PT: dizziness, } \\
\text { fever and } \\
\text { fatigue; elevated } \\
\text { aminotransferases }\end{array}$ & TDF \\
\hline $6[10]$ & $\begin{array}{l}83 \text { yo, } \\
\text { female }\end{array}$ & $\begin{array}{c}\text { HBsAg } \\
\text { negative }\end{array}$ & $\begin{array}{c}\mathrm{G} 1 \mathrm{~b} \\
\text { Experienced } \\
(\mathrm{INF}+\mathrm{RBV})\end{array}$ & Yes & No & $\mathrm{DCV}+\mathrm{ASU}$ & $\begin{array}{l}\text { W20 PT: elevated } \\
\text { transaminases }\end{array}$ & ETC \\
\hline $7[11]$ & $\begin{array}{l}54 \text { yo, } \\
\text { female }\end{array}$ & $\begin{array}{l}\text { "Resolved" } \\
\text { infection }\end{array}$ & $\begin{array}{c}\text { G4 } \\
\text { Treatment naïve }\end{array}$ & No & Yes & SOF/LDV & $\begin{array}{l}\text { W12 PT: nausea, } \\
\text { vomiting, } \\
\text { jaundice, } \\
\text { abdominal pain }\end{array}$ & ETC \\
\hline $8[12]$ & $\begin{array}{l}62 \text { yo, } \\
\text { female }\end{array}$ & $\begin{array}{l}\text { "Resolved" } \\
\text { infection }\end{array}$ & $\begin{array}{c}\text { G2 } \\
\text { Treatment naïve }\end{array}$ & No & No & $\mathrm{SOF}+\mathrm{RBV}$ & $\begin{array}{l}\text { W24PT: nausea } \\
\text { and fatigue }\end{array}$ & TDF \\
\hline 9 [13] & $\begin{array}{l}53 \text { yo, } \\
\text { male }\end{array}$ & $\begin{array}{l}\text { Inactive } \\
\text { chronic } \\
\text { hepatitis }\end{array}$ & $\begin{array}{c}\text { G1b } \\
\text { Treatment } \\
\text { experienced } \\
\text { (pegINF + RBV) }\end{array}$ & Unknown & No & SOF/LDV & $\begin{array}{c}\text { W4 HCV } \\
\text { treatment: } \\
\text { malaise, choluria, } \\
\text { elevated } \\
\text { transaminases }\end{array}$ & ETC \\
\hline $10[14]$ & $\begin{array}{l}46 \text { yo, } \\
\text { female }\end{array}$ & $\begin{array}{l}\text { Inactive } \\
\text { chronic } \\
\text { hepatitis }\end{array}$ & $\begin{array}{c}\text { G2a } \\
\text { Treatment naïve }\end{array}$ & Unknown & No & $\mathrm{SOF}+\mathrm{RBV}$ & $\begin{array}{c}\text { EOT: } \\
\text { asymptomatic } \\
\text { HBV DNA increase }\end{array}$ & None \\
\hline $11[14]$ & $\begin{array}{l}64 \text { yo, } \\
\text { female }\end{array}$ & $\begin{array}{l}\text { Inactive } \\
\text { chronic } \\
\text { hepatitis }\end{array}$ & $\begin{array}{c}\text { G1b } \\
\text { Treatment naïve }\end{array}$ & Unknown & No & OBV/PTV/r & $\begin{array}{c}\text { Asymptomatic } \\
\text { HBV DNA increase } \\
\text { during treatment }\end{array}$ & None \\
\hline
\end{tabular}

yo - years old, G - genotype, INF - interferon, peg-INF - peginterferon, RBV - ribavirin, SOF - sofosbuvir, LDV - ledipasvir, DCV - daclatasvir, SIM - simeprevir, ASU - asunaprevir, OBV - ombistasvir, PTV - paritraprevir, $r$ - ritonavir, W-week, PT-post-treatment, TDF - tenofovir, FTC - emtricitabine, ETC - entecavir

positive patients had a reactivation [29]. It should be noted, however, that these studies only followed-up patients for 12 weeks after treatment and, as demonstrated in our case, the event may happen after this time period.

Due to the persistence of $\mathrm{HBV}$ in the form of cccDNA in hepatocytes and other tissues, the reactivation of hepatitis B is a well know possibility in the setting of immunosuppression [30]. Although the potential protective role of the anti-HBs antibodies is controversial, the risk of HBV reactivation is considered lower than in those without HBsAb $[21,30]$. Our case and case 7, both describe HBV reactivation in $\mathrm{HBs} A b$ positive patients, which means that clinicians should moni- 
tor patients with serological markers of "resolved" HBV infection. In both cases of reactivation with anti-HBs antibody, patients were HIV-coinfected, and studies have shown that HIV-related immunosuppression plays a deleterious role on HBV infection with higher rates of chronicity, positive antigenemia, chronic liver disease, and even HBV reactivation $[21,31]$. Fabbri et al. (case 7) describe a case of an immunocompromised HIV patient with low values of anti-HBsAb when he started ART without any HBV active drug (boosted darunavir and etravirine). Six months later, he had unmeasurable HBsAb levels, and DAA treatment for HCV was started; the patient had HBV reactivation [11]. However, in this case, the authors draw attention to the fact that in immunocompromised HIV patients, many factors may play a role besides DAA treatment, namely immune reconstitution syndrome [11]. However, HIV was well controlled in our patient and in patient from case 5; CD4+ lymphocyte count was above $500 \mathrm{~mm}^{3}$ in both cases.

Reports of reactivation of HBV during or after treatment of hepatitis $C$ with DAAs have prompted both EMA and FDA to recommend screening for all patients initiating hepatitis $\mathrm{C}$ treatment with these drugs, and close surveillance of patients with markers of hepatitis $B$ previous infection [16, 17]. Similarly, both European and American guidelines on HCV treatment suggest caution when treating $\mathrm{HCV}$ infection in patients with serological evidence of previous HBV infection $[19,20]$. The AASLD/IDSA guidelines recommend performing HBV DNA testing in patients with positive $\mathrm{HBsAg}$, and starting $\mathrm{HBV}$ therapy at the same time or before DAA initiation in those that meet HBV treatment criteria and to regularly monitor those with low or undetectable HBV DNA [20]. However, none of these documents provides guidance on how to monitor those who are $\mathrm{HBsAg}$ negative, which markers of active HBV disease (aminotransferases, HBV DNA, or HBs antigen) should be used to monitor these patients, at which intervals, or for how long.

In addition, how to manage patients after an HBV reactivation is not fully clarified. EMA and FDA report guidelines to each disease $[16,17]$ but some authors advocate initiation of preemptive therapy in those still asymptomatic with analytical evidence of reactivation [7]. This seems to be the most usual attitude described in clinical cases reports [6-13]; however, only $52 \%$ of the cases reported to FDA received HBV therapy with entecavir or tenofovir [15]; Sato et al. reported two cases of spontaneous HBV remission [14]. Despite these reports, there have been cases of fulminant hepatic failure, liver transplantation, and death in patients with HBV reactivation related to DAA treatment $[8,22]$.

We know from literature that the interaction between HCV and HBV is complex and not completely understood $[2,21]$. With the tolerability of DAAs and their high SVR rates, many $\mathrm{HCV} / \mathrm{HBV}$-coinfected patients will be cured of HCV infection and therefore, as an unintended consequence, the immunosuppressive effects of $\mathrm{HCV}$ on $\mathrm{HBV}$ will be lost and there will be room for HBV reactivation. Due to the potential severity of HBV reactivation that can lead to hepatic failure and hepatic transplantation, clinicians should both be aware and closely monitor patients with evidence of previous $\mathrm{HBV}$ infection.

\section{Conflict of interest}

The authors declare no potential conflicts of interest with respect to the research, authorship, and/or publication of this article.

\section{References}

1. WHO. http://www.who.int/hiv/topics/hepatitis. Accessed: July 2017.

2. Konstantinou D, Deutsch M. The spectrum of HBV/HCV coinfection: epidemiology, clinical characteristics, viral interactions and management. Ann Gastroenterol 2015; 28: 221-228.

3. Potthoff A, Wedemeyer H, Boecher WO, et al. The HEP-NET B/C co-infection trial: A prospective multicenter study to investigate the efficacy of pegylated interferon-alpha $2 \mathrm{~b}$ and ribavirin in patients with HBV/HCV co-infection. J Hepatol 2008; 49: 688-694.

4. Liu JY, Sheng YJ, Hu HD, et al. The influence of hepatitis B virus on antiviral treatment with interferon and ribavirin in Asian patients with hepatitis $\mathrm{C}$ virus/hepatitis $\mathrm{B}$ virus coinfection: a meta-analysis. Virol J 2012; 9: 186.

5. Arends JE, Lieveld FI, Boeijen LL, et al. Natural history and treatment of $\mathrm{HCV} / \mathrm{HIV}$ coinfection: Is it time to change paradigms? J Hepatol 2015; 63: 1254-1262.

6. Takayama H, Sato T, Ikeda F, et al. Reactivation of hepatitis B virus during interferon-free therapy with daclatasvir and asunaprevir in patient with hepatitis $B$ virus/hepatitis $C$ virus co-infection. Hepatol Res 2016; 46: 489-491.

7. Collins JM, Raphael KL, Terry C, et al. Hepatitis B Virus Reactivation During Successful Treatment of Hepatitis C Virus With Sofosbuvir and Simeprevir. Clin Infect Dis 2015; 61: 1304-1306.

8. Ende AR, Kim NH, Yeh MM, et al. Fulminant hepatitis B reactivation leading to liver transplantation in a patient with chronic hepatitis $\mathrm{C}$ treated with simeprevir and sofosbuvir: a case report. J Med Case Rep 2015; 9: 164.

9. De Monte A, Courjon J, Anty R, et al. Direct-acting antiviral treatment in adults infected with hepatitis $C$ virus: Reactivation of hepatitis B virus coinfection as a further challenge. J Clin Virol 2016; 78: 27-30.

11. Fabbri G, Mastrorosa I, Vergori A, et al. Reactivation of occult HBV infection in an HIV/HCV co-infected patient successfully treated with sofosbuvir/ledipasvir: a case report and review of the literature. BMC Infect Dis 2017; 17: 182.

12. Madonia S, Orlando L, Madonia G, et al. HCV/HIV coinfection: the dark side of DAAs treatment? Liver Int 2017; 37: 1086-1087.

13. Ou P, Fang X, Chen J, et al. Hepatitis B reactivation in a chronic hepatitis $\mathrm{C}$ patient treated with ledipasvir and sofosbuvir: A case report. Clin Res Hepatol Gastroenterol 2017; 41: e17-e18.

14. Sato K, Kobayashi T, Yamazaki Y, et al. Spontaneous remission of hepatitis B virus reactivation during direct-acting antiviral agent-based therapy for chronic hepatitis C. Hepatol Res 2017; 47: 1346-1353.

15. Bersoff-Matcha SJ, Cao K, Jason M, et al. Hepatitis B Virus Reactivation Associated With Direct-Acting Antiviral Therapy for Chronic Hepatitis C Virus: A Review of Cases Reported to the U.S. Food and Drug Administration Adverse Event Reporting System. Ann Intern Med 2017; 166: 792-798.

16. EMA. Direct-acting antivirals for hepatitis C: EMA confirms recommendation to screen for hepatitis B. Available at: www.ema. europa.eu/ (Accessed: July 2017).

17. FDA. FDA Drug Safety Communication: FDA warns about the risk of hepatitis B reactivating in some patients treated with directacting antivirals for hepatitis C. Available at: www.fda.gov (Accessed: July 2017). 
18. World Health Organization. Guidelines for the screening, care and of persons with chronic hepatitis C infection: Update Version (Accessed: April 2016).

19. European Association for Study of Liver. EASL Recommendations on Treatment of Hepatitis C 2015. J Hepatol 2015; 63: 199-236.

20. AASLD/IDSA HCV Guidance Panel. AASLD-IDSA recommendations for testing, managing, and treating adults infected with hepatitis C virus. Available at: http://www.hcvguidelines.org (Accessed: July 2017).

21. Soriano V, Labarga P, de Mendoza C, et al. Emerging challenges in managing hepatitis B in HIV patients. Curr HIV/AIDS Rep 2015; 12: 344-352.

22. Sidharthan S, Kohli A, Sims Z, et al. Utility of hepatitis C viral load monitoring on direct-acting antiviral therapy. Clin Infect Dis 2015; 60: 1743-1751.

23. Wahle RC, Perez RM, Pereira PF, et al. Hepatitis B virus reactivation after treatment for hepatitis $\mathrm{C}$ in hemodialysis patients with HBV/HCV coinfection. Braz J Infect Dis 2015; 19: 533-537.

24. Sulkowski MS, Chuang WL, Kao JH, et al. No Evidence of Reactivation of Hepatitis B Virus Among Patients Treated with LedipasvirSofosbuvir for Hepatitis C Virus Infection. Clin Infect Dis 2016; 63: 1202-1204.

25. Belperio PS, Shahoumian TA, Mole LA, et al. Evaluation of hepatitis $B$ reactivation among 62,920 veterans treated with oral hepatitis C antivirals. Hepatology 2017; 66: 27-36.

26. Liu CH, Liu CJ, Su TH, et al. Hepatitis B Virus Reactivation in $\mathrm{Pa}$ tients Receiving Interferon-Free Direct-Acting Antiviral Agents for Chronic Hepatitis C Virus Infection. Open Forum Infect Dis 2017; 4: of 028 .

27. Wang C, Ji D, Chen J, et al. Hepatitis due to Reactivation of Hepatitis B Virus in Endemic Areas Among Patients With Hepatitis C Treated With Direct-acting Antiviral Agents. Clin Gastroenterol Hepatol 2017; 15: 132-136.

28. Londoño MC, Lens S, Mariño Z, et al. Hepatitis B reactivation in patients with chronic hepatitis $\mathrm{C}$ undergoing anti-viral therapy with an interferon-free regimen. Aliment Pharmacol Ther 2017; 45: 1156-1161.

29. Yeh ML, Huang CF, Hsieh MH, et al. Reactivation of hepatitis B in patients of chronic hepatitis $\mathrm{C}$ with hepatitis $\mathrm{B}$ virus infection treated with direct acting antivirals. J Gastroenterol Hepatol 2017; 32: 1754-1762.

30. Pattullo V. Prevention of Hepatitis $B$ reactivation in the setting of immunosuppression. Clin Mol Hepatol 2016; 22: 219-237.

31. Sun HY, Sheng WH, Tsai MS, et al. Hepatitis B virus coinfection in human immunodeficiency virus-infected patients: a review. World J Gastroenterol 2014; 20: 14598-14614. 